\title{
Aspects of weather parameters at Neumayer station, Antarctica, and their representation in reanalysis and climate model data
}

\author{
Milan Klöwer, Thomas Jung, Gert König-Langlo and Tido SemmLeR* \\ Alfred Wegener Institute, Helmholtz Centre for Polar and Marine Research, Bremerhaven, Germany \\ (Manuscript received May 16, 2013; in revised form September 17, 2013; accepted September 18, 2013)
}

\begin{abstract}
ERA-Interim reanalysis data and data of the Hadley Centre Global Environmental Model version 2 (HadGEM2) are compared with continuous meteorological observations of near-surface wind and temperature carried out for more than 30 years at Neumayer station, situated on the Ekström Ice Shelf of Antarctica. Significant temperature correlations between Neumayer climate and the climate of both the interior of the Antarctic continent and oceanic regions north of Neumayer are investigated using observational data and model data. Mean sea level pressure fluctuations at Neumayer can be connected to changes in the Southern Annular Mode (SAM). Shortcomings in the ERA-Interim reanalysis data with spurious trends of up to $7{ }^{\circ} \mathrm{C}$ over 31 years are identified at several places in Antarctica. Furthermore, it is shown that katabatic winds in both the ERA-Interim reanalysis data and in the HadGEM2 climate model are underrepresented in frequency and speed, presumably due to the problems in representing topography in these relatively coarse resolution models. This may be one reason for the positive $2 \mathrm{~m}$ air temperature bias of $3{ }^{\circ} \mathrm{C}$ in the models at Neumayer station. The results of this study reemphasize that climatic trends in regions with a low station density can not be assessed solely from model data. Thus, it is absolutely necessary to maintain polar observatories such as Neumayer station to quantify climate change over the Southern Ocean and Antarctica.
\end{abstract}

Keywords: Antarctica, Neumayer, observations, katabatic winds, Southern Annular Mode, reanalysis, climate model.

\section{Introduction}

Antarctica with its vast ice sheets plays an important role in the global climate system. Observations show that except for the Antarctic Peninsula and West Antarctica (BROMWICH et al., 2013), the polar continent has not warmed as much during the last 30 years as other areas of the globe; in fact, near-surface temperature has even cooled in some central parts of Antarctica (CHAPMAN and Walsh, 2007; Steig et al., 2009; MONAGHAN et al., 2008; TURNER et al., 2005). Monitoring the Antarctic climate system is hampered by the relative lack of observational data. The instrumental records that are available come from manned polar research stations, automatic weather stations, and satellite platforms (CHAPMAN and WALSH, 2007). For logistical reasons, most of the observatories are concentrated along the Antarctic coast. The sparse observational coverage poses two questions when investigating Antarctic weather and climate, which will be investigated in this study:

\footnotetext{
"Corresponding author: Tido Semmler, Alfred Wegener Institute, Helmholtz Centre for Polar and Marine Research, Am Handelshafen 12, 27570 Bremerhaven, Germany, e-mail: Tido.Semmler@awi.de
}

- What is the spatial footprint of the observation station?

- How well do reanalysis products and climate models reproduce the observational data?

where we define spatial footprint as the regions that are significantly temporally correlated to measurements at Neumayer station concerning meteorological variables.

Previous studies have investigated some aspects of the accuracy of several global reanalyses over the Southern Hemisphere (RODRIGO et al., 2013; BRACEGIRDLE and MARSHALl, 2012). BROMWICH and FoGT (2004), for example, show that the quality of ERA-40 and NCEPNCAR reanalyses increased strongly with the availability of satellite data after 1978. Here we point out serious shortcomings in the ERA-Interim reanalysis data also in the satellite era.

A specific meteorological feature of the Antarctic continent is the existence of strong katabatic winds, which are known to dominate weather and climate in certain regions of Antarctica. PARISH (1988); PARISH and BROMWICH (2007) and TURNER et al. (2009) describe katabatic winds, which occur mainly due to cooling of the lower atmosphere on the Antarctic interior. Especially in winter, when the absence of solar irradiance results in strong 
inversions on the Antarctic continent, the density of nearsurface air masses increases. This leads to downslopedirected horizontal density gradients between very cold air masses and relatively warm air masses. The resulting force is dependent on the inversion strength and the steepness of the terrain slope. As a consequence the denser air slides down the slope and its strength and direction is mainly determined by topographic steering. In fact, PARISH (1988) and VAN LIPZIG et al. (2004) show that katabatic winds converge inhomogeneously into several, unequally distributed confluence zones. The representation of katabatic winds in climate models is an important issue, given their strong impact on coastal air-sea-ice heat exchange, sea-ice thickness and the extent of coastal polynyas (MATHIOT et al., 2010; PETRELLI et al., 2008). Hence, katabatic winds influence the deep and bottom water formation at the Antarctic coast with important implications for the world's oceans. The application of downscaling makes clear that katabatic winds are in principle included in climate models as shown by VAN DEN BROEKE et al. (1997), but higher spatial resolution of models is necessary for a more realistic representation of sub-synoptic and meso-scale features (RODRIGO et al., 2013; PARISH and BROMWICH, 2007).

The Neumayer station is situated on the Ekström Ice Shelf about $42 \mathrm{~m}$ above sea level (approximate elevation due to tidal changes and replacement of the station) and $5 \mathrm{~km}$ away from the southeast part of Atka Bay (see Fig. 2). The Ekström Ice Shelf has a homogeneous, flat surface, sloping upward to the south towards a high plateau. It is a site where katabatic winds occur regularly. Nowadays the station provides more than 30 years of continuous synoptic observations since its launch in March 1981. Given the length of the time series, it can be officially classified as a climate station. Unlike the Antarctic Peninsula, there is no significant trend in the observed temperature at Neumayer from 1981 to 2011, which is in agreement with most of the other Antarctic stations (MONAGHAN et al., 2008; KÖNIG-LANGLO and LOOSE, 2007). Neumayer station provides a wealth of data. However, so far these data have not been fully exploited. The purpose of this study is to establish the value of Neumayer station to advance our understanding of the climate system. More specifically, this study aims:

- to investigate the spatial footprint of the Neumayer station on Antarctica and the surrounding sea areas,

- to study circulation patterns associated with anomalously warm and cold temperatures at Neumayer, and

- to explore the accuracy of reanalyses and climate model simulations over Antarctica.

The performance of the ERA-Interim reanalysis is validated making use of measurements carried out at Neumayer station. Additionally, we analyze the climate model HadGEM2 with the same methods for compari- son. Section 2 describes the data and methods employed. In section 3 spatial pressure and temperature correlations are considered for the Southern Hemisphere to quantify the representativeness of the Neumayer station. Problems in simulating physically reasonable temperature time series in ERA-Interim will be described and discussed in section 4. Section 5 focuses on the comparison between observed and simulated winds, which includes the investigation of winds during anomalous temperatures at Neumayer station. Finally, section 6 summarizes the results and draws a conclusion.

\section{Data and methodology}

We analyze $2 \mathrm{~m}$ temperature, $10 \mathrm{~m}$ wind and sea level pressure (SLP) of synoptic meteorological observations from Neumayer station between March 1981 and December 2011. During this period, 3-hourly measurements were carried out continuously, first at the former Georg-von-Neumayer station $\left(70^{\circ} 37^{\prime} \mathrm{S}, 8^{\circ} 22^{\prime} \mathrm{W}\right)$ until March 1992, second at the Neumayer station II (70³9' S, $8^{\circ} 15^{\prime} \mathrm{W}$ ) and since February 2009 at the Neumayer station III ( $70^{\circ} 40^{\prime} \mathrm{S}, 8^{\circ} 16^{\prime} \mathrm{W}$ ) (see KÖNIG-LANGLO and LOOSE (2007) for details). The three meteorological parameters are measured every three hours as mean values over 10 minutes. The three stations are all located several kilometers apart from each other on the Ekström ice shelf close to the Atka Bay and will be referred to jointly as Neumayer station (location is denoted in Fig. 2). All the data used here are available through Pangaea (KLÖWER et al., 2013).

In addition, we analyze data from the ERA-Interim reanalysis (DEE et al., 2011) and the global coupled climate model HadGEM2 (Collins et al., 2011), which contributed to the Coupled Model Intercomparison Project Phase 5 (CMIP5). For the HadGEM2 model, historical solar, greenhouse gas, and aerosol concentration forcing was used until 2005; afterwards, data from the HadGEM2 scenario simulation with greenhouse gas and aerosol concentrations from the representative concentration pathway 4.5 (RCP 4.5) defined in CMIP5 have been used (for details see MEINSHAUSEN et al. (2011); JONES et al. (2011)). For both the historical and the scenario simulations, the first ensemble member has been considered. RCP 4.5 is a moderate scenario and it is adequate to make use of it until 2011. As can be seen e.g. from Fig. 1 of ARORA et al. (2011), up to 2020 there is no discernible difference between even the strongest and the weakest emission scenario in the $\mathrm{CO}_{2}$ concentration and in the global mean temperature.

In order to obtain anomalous temperatures at Neumayer station for subsequent wind composite analysis, multi-year daily temperature averages were formed. In the following, an event of temperatures more than one standard deviation above (below) the long-term average shall be referred to as warm event (cold event). The threshold of one standard deviation, which leads to a 

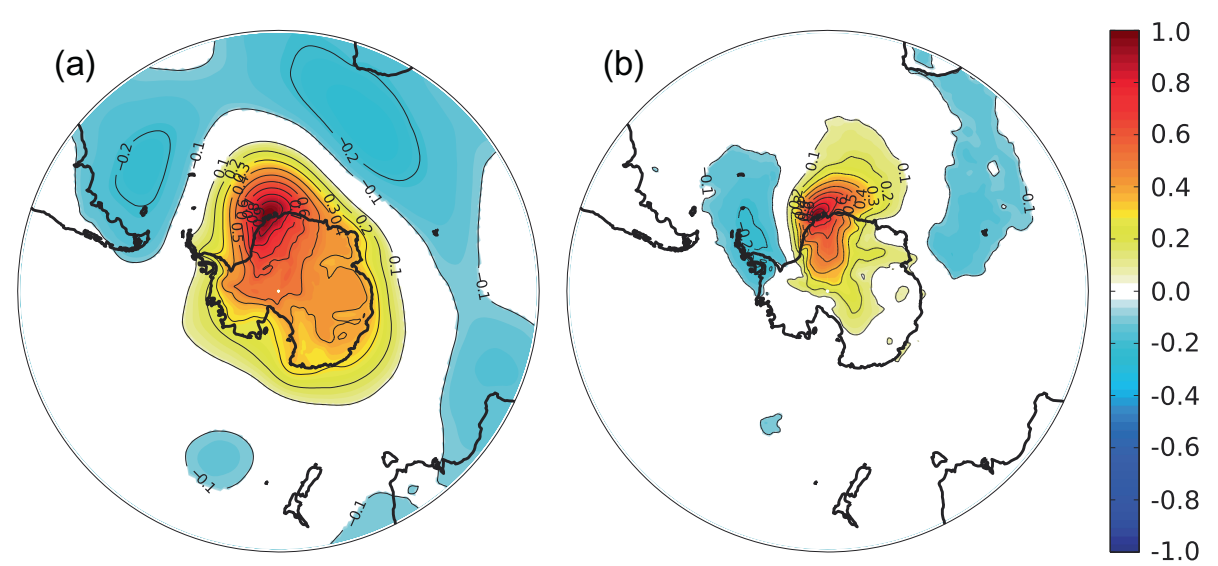

Figure 1: Correlation of ERA-Interim daily anomalies with Neumayer observations during winter (JJA): (a) SLP, (b) Temperature. The areas where the correlation is non-significant at the 95\%-level (two sided $t$-test) has been left blank. The Neumayer station is located at the correlation maximum, respectively.

selection of about $16 \%$ of all days as warm (cold) events, is chosen not too high to get a large sample of warm (cold) days. The same procedure has been carried out for HadGEM2. Since ERA-Interim time series of Neumayer temperature have large inconsistencies (see section 4) observed rather than reanalyzed temperatures were used for the selection of warm (cold) days for building the corresponding ERA-interim wind composites. Different statistical tests were applied for significance testing. Correlation and trends have been tested with a two-sided $t$-test, as is common practice. To test the significance of the composite maps a two-sided Mann-Whitney-Wilcoxon test (MANN and WHITNEY, 1947), was applied in order to be able to deal with different sample sizes. This non-parametric test is designed to analyze whether one of two random variables is coming from a distribution with different median. Mathematically, the sum of ranks is computed, which follows a normal distribution for large samples. This is in contrast to using the original values of the samples according to the t-test which can only be applied if the data values follow a normal distribution. Furthermore, this choice takes into account the fact that wind speeds are not normally distributed (RODRIGO et al., 2013; RIMBU et al., 2013). For the same reason composite maps are based on the median of the distribution rather than the commonly used arithmetic mean.

In order to make observational data more directly comparable to daily values of reanalysis and climate model data, we averaged the 3-hourly measurements of 10 minute averages arithmetically for each day. Wind speed and direction was transformed into its $u$ - and $v$-component to calculate a vector mean.

The resolution of ERA-Interim is approximately $80 \mathrm{~km}$ (North-South) $\times 25 \mathrm{~km}$ (East-West) in the area around Neumayer station; in comparison to this the resolution of the HadGEM2 model is coarser at $140 \mathrm{~km} \times$ $70 \mathrm{~km}$. In section 5 , we refrained from interpolating the reanalysis and model data to the exact location of
Neumayer station given that the nearest ERA-Interim and HadGEM2 grid points are no more than $18 \mathrm{~km}$ far away (the distance to the ice shelf edge is also comparable). We recognize a general difference between model data and observations: Gridded data is always the respresentation of an averaged value over a certain area, whereas an observation is just representative for a point in space where the measurement has been carried out. Nevertheless, as the area around Neumayer station is reasonably flat and homogeneous, we proceed with the comparison bearing this difference in mind.

The ability of the reanalysis and the climate model to simulate complex ageostrophic wind components, such as katabatic winds, is investigated by the analysis of geostrophic wind components $u_{\mathrm{g}}, v_{\mathrm{g}}$ (on a longitude-latitude grid), which were calculated from model output as following:

$$
u_{g}=-\frac{1}{f \rho} \frac{\partial p}{\partial y}, \quad v_{g}=\frac{1}{f \rho} \frac{\partial p}{\partial x}
$$

where $f=f(y)$ refers to the coriolis parameter, $p$ is the sea level pressure (SLP), $\rho=\rho\left(p_{\text {surf, }} h, T\right)$, is the in-situ density calculated from the ambient surface pressure $p_{\text {surf, }}$, the humidity $h$ and the ambient temperature $T$.

\section{Spatial footprint of the Neumayer station}

Fig. 1 shows the temporal correlation of daily anomalies of SLP and $2 \mathrm{~m}$ temperature between Neumayer station and ERA-Interim reanalysis data over the Southern Hemisphere during winter. Other seasons were investigated as well but here it was decided to focus on the winter months only. The phenomena described in the following are very similar to those found in spring, summer and autumn. However, the magnitude of anomalies peak during austral winter due to the relatively high level of atmospheric variability (KÖNIG-LANGLO and LOOSE, 2007). In summer the meridional temperature gradient 


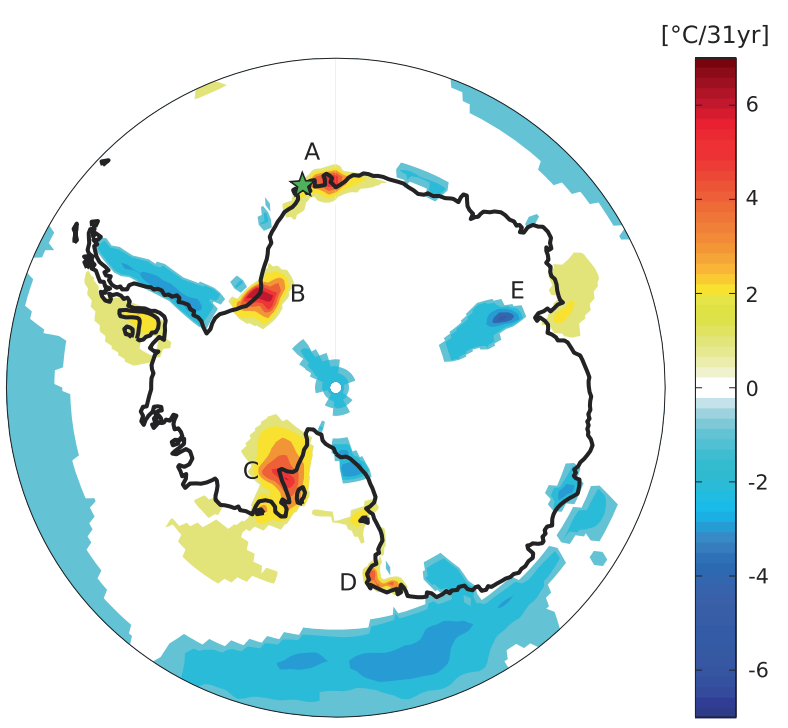

Figure 2: Linear trend of $2 \mathrm{~m}$ temperatures $\left[{ }^{\circ} \mathrm{C} / 31 \mathrm{yr}\right]$ of monthly anomalies in ERA-Interim over the period of 31 years from 1981 to 2011. The area where the trend is insignificant at the $99 \%$-level (two sided $t$-test) has been left blank. Positions A to E each refer to the local extremum. The Neumayer station is denoted with a green star symbol.

is comparably weak leading to weaker temperature differences between northerly and southerly winds and hence reduced anomalies.

The Southern Annular Mode (SAM) is the dominant pattern of atmospheric variability on the Southern Hemisphere (THOMPSON and WALLACE, 2000; GONG and WANG, 1999), which describes simultaneous variations of atmospheric pressure at high- and mid-latitudes. The centers of action are located approximately at $40^{\circ} \mathrm{S}$ and $65^{\circ} \mathrm{S}$ and are hardly dependent on the longitude. Hence, the SAM index is a measurement for the strength of circumpolar westerlies, which imprints many climatic parameters of Antarctica (THOMPSON and SOLOMON, 2002) as well as of the Southern Ocean (HALL and VISBECK, 2002) through heat and momentum fluxes. GONG and WANG (1999) define a SAM Index by the zonal mean difference of SLP between $40^{\circ} \mathrm{S}$ and $65^{\circ} \mathrm{S}$. The observed daily SLP at Neumayer station explains $30.1 \%$ of the variability of the daily SAM Index calculated as defined by GONG and WANG (1999) from ERA-Interim data. The correlation coefficient is -0.55 , which is significant at the $99.99 \%$-level. Hence, the pattern that appears in Fig. 1(a) is in good agreement with the Southern Annular Mode (SAM) as it can be seen in Fig. 2 of VISBECK (2009). In summary, therefore, it can be said that SLP observations at Neumayer station reflect changes in the SAM. The pattern of the SAM emerges even more clearly when monthly-mean anomalies are considered (not shown), which is clear considering the higher correlation coefficient of -0.72 for monthly-mean anomalies (significant at the 99.99\%level) and the higher explained variance of $52.5 \%$. This agrees well with the findings of RIMBU et al. (2013), who show that enhanced variability at monthly time scales in the observational record at Neumayer station is associated with the SAM.

The spatial pattern of correlation in temperatures (Fig. 1(b)) shows a significant signal of the same sign extending all the way from Southern Ocean to the South Pole. Areas of opposite temperature anomalies appear to the west and east over the Southern Ocean; they can be explained by the atmospheric Rossby waves of the large-scale circulation, so that a wave crest and trough are accompanied in the east-west direction inducing opposite anomalies. This wave pattern is prominent in the sector from approximately $90^{\circ} \mathrm{W}-90^{\circ} \mathrm{E}$ (RIMBU et al., 2013). Furthermore, West Antarctica seems to be separated, which can be explained by the topographic division of these parts of Antarctica by the Transantarctic Mountains (MONAGHAN et al., 2005). In summary, measurements carried out at Neumayer clearly reflect nonlocal anomalies across large areas of Antarctica and the Southern Ocean.

\section{Trends in temperature}

This section deals with the reanalyzed and observed trends in $2 \mathrm{~m}$ temperature in ERA-Interim over the Antarctic region from 1981 to 2011 for all seasons. Apart from a more general description of the trends their physical plausibility will be discussed in further detail.

Fig. 2 shows the temperature trends from 1981 to 2011 in the Antarctic region. The trends were calculated as the slope of the linear regression over the period of 31 years (all seasons) for each grid point. The most prominent features are 4 different small areas (positions A to D) where temperature has increased by $5-7^{\circ} \mathrm{C}$. Such a strong localized warming has not been identified in any observation studies, with the exception of the Antarctic Peninsula (CHAPMAN and WALSH (2007); STEIG et al. (2009)). The trends obtained from HadGEM2 reveal a rather smoothed pattern of slightly increasing temperatures (not shown). In the following, three different locations of suspiciously high temperature trends in ERA-Interim will be investigated in more detail: Position A, which is located close to the Neumayer station, as well as position $\mathrm{D}\left(170.2^{\circ} \mathrm{E}, 72.6^{\circ} \mathrm{S}\right)$ and position $\mathrm{E}\left(67.5^{\circ} \mathrm{E}\right.$, $\left.73.3^{\circ} \mathrm{S}\right)$. The spurious temperature trend in position $\mathrm{E}$ was shown by DEE et al. (2011) (their Fig. 36(c)).

The time series of monthly temperature anomalies from Neumayer station and ERA-Interim are shown in Fig. 3(a) and Fig. 3(b), respectively. For this analysis the ERA-Interim data were linearly interpolated to the exact location of Neumayer station. Linear regressions are applied for the periods 1981-2001 and 2002-2011 separately. The time series was splitted into two periods because ERA-Interim shows an abrupt temperature increase of about $1.5^{\circ} \mathrm{C}$ from 2001 to 2002 ; such a shift is absent from the observational time series from Neumayer station. The correlation coefficient between ERA-Interim and the observations amounts to 0.82 for 
$\left[{ }^{\circ} \mathrm{C}\right]$

(a)

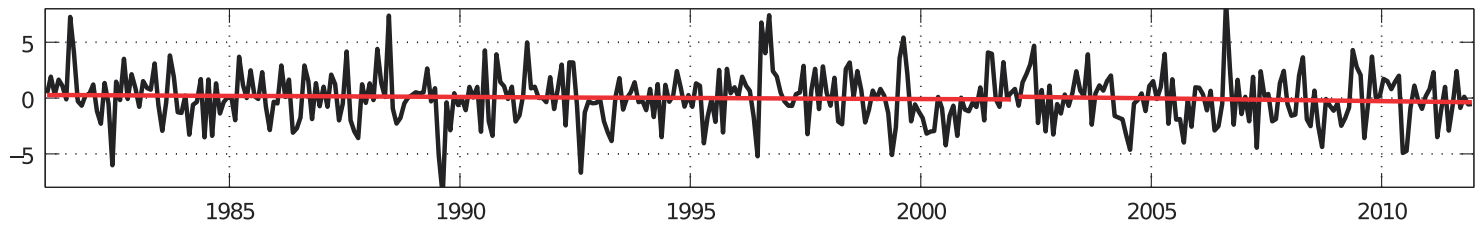

$\left[{ }^{\circ} \mathrm{C}\right]$

(b)

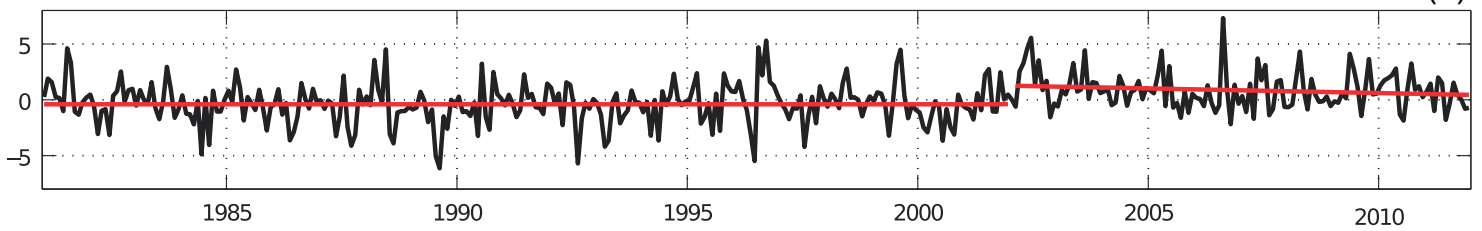

$\left[{ }^{\circ} \mathrm{C}\right]$

(c)

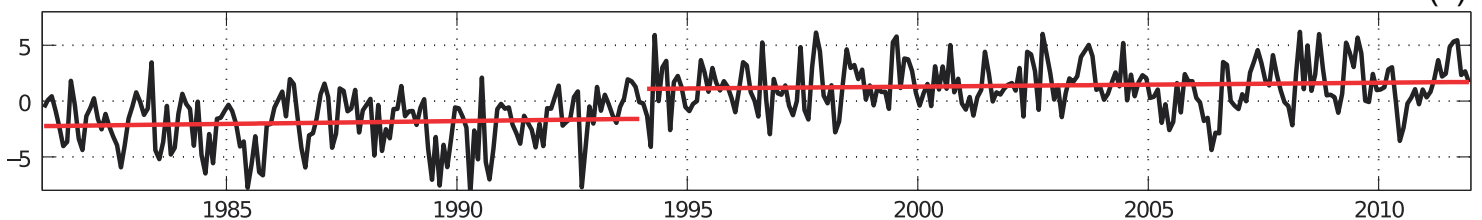

$\left[{ }^{\circ} \mathrm{C}\right]$

(d)

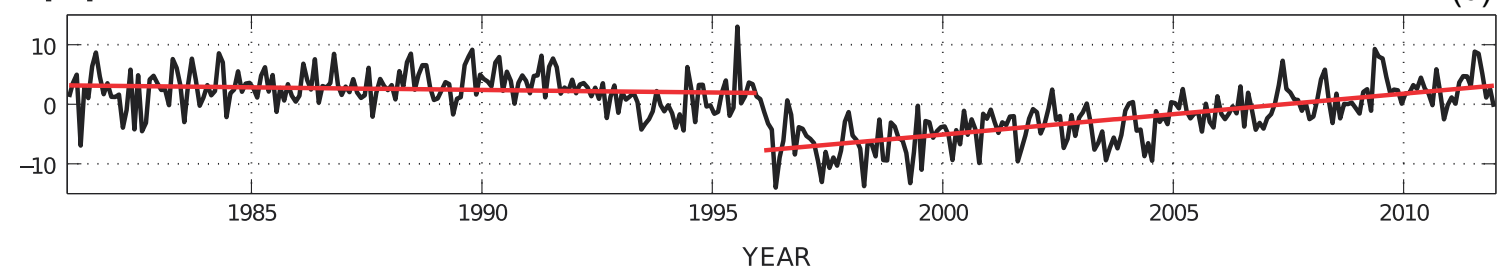

Figure 3: Time series of monthly anomalies in $2 \mathrm{~m}$ temperature $\left[{ }^{\circ} \mathrm{C}\right]$ for (a) Observations at Neumayer station, (b) ERA-Interim linearly interpolated on the Neumayer position, (c) ERA-Interim at position D, (d) ERA-Interim at position E, as marked in Fig. 2. Linear regressions have been applied over different periods: (a) 1981-2001 and 2002-2011, (b) as in (a), (c) 1981-1993 and 1994-2011, (d) 19811996 and 1997-2011. Please note that the scaling for (d) is different from (a),(b) and (c).

the full period 1981-2011. The correlation is higher for the first period (0.90) and comparable to the full record for the second period (0.83). ERA-Interim seems to have more problems in representing anomalously cold $2 \mathrm{~m}$ temperature events after the shift in 2001/02.

Fig. 3(c) and (d) show the time series of ERA-Interim data for position D and E. For position D a linear regression has been applied for the periods 1981-1994 and 1995-2011. Further analysis shows a shift in temperature of $3.3{ }^{\circ} \mathrm{C}$ between these periods. At position $\mathrm{E}$ a marked temperature discontinuity appears between 1995 and 1996 , which is followed by an increase of about $11^{\circ} \mathrm{C}$ over 16 years.

These examples show that reanalysis efforts are challenging in an environment where the temporal and spatial coverage of instrumental records is very limited. The reasons for the above-mentioned spurious temperature shift remain to be fully understood. However, one possible explanation is that ERA-Interim has problems when manned stations or automatic weather stations become available or unavailable for a longer period of time. It is also conceivable that there are issues with the bias correction scheme and the availability of station data.
Table 1: Comparison of mean values and temperature trends at Neumayer station during 1981-2011 in observations, ERA-Interim and HadGEM2. Linear interpolation has been applied for the geopraphical position of Neumayer station $(8.3 \mathrm{~W}, 70.7 \mathrm{~S})$. Please note that the mean value for wind speed is the velocity of a vector mean, as described in section 2 .

\begin{tabular}{lccc}
\hline & Observations & ERA-Interim & HadGEM2 \\
\hline Elevation $[\mathrm{m}]$ & 42.0 & 31.6 & 130.1 \\
Temperature $\left[{ }^{\circ} \mathrm{C}\right]$ & -15.9 & -13.0 & -14.0 \\
T trend $\left[{ }^{\circ} \mathrm{C} / 31 \mathrm{y}\right]$ & -0.42 & 1.53 & 1.38 \\
SLP $[\mathrm{hPa}]$ & 986.6 & 986.5 & 986.9 \\
wind speed $[\mathrm{m} / \mathrm{s}]$ & 8.3 & 7.1 & 5.6 \\
\hline
\end{tabular}

Table 1 shows elevation, mean temperature, temperature trend, mean SLP and mean wind speed for comparison between observations, reanalysis, and the model. For HadGEM2 it has to be noted that the geographical position of Neumayer station is located at an elevation of approx. 130m; this mismatch can be explained by the relatively coarse resolution of the model. This elevation difference may result in a possible $2 \mathrm{~m}$ temperature bias in 

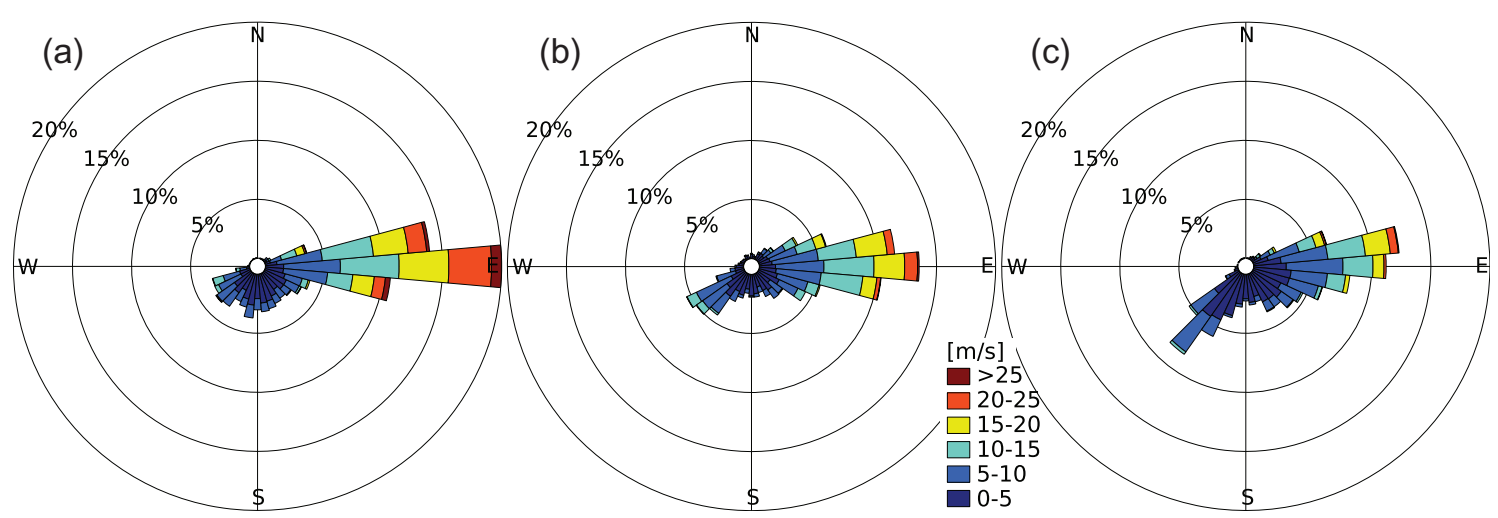

Figure 4: Two-dimensional frequency distribution of daily 10m winds at Neumayer station during winter months (JJA) from 1981 to 2011: (a) Observations, (b) ERA-Interim, (c) HadGEM2.

the order of $1{ }^{\circ} \mathrm{C}$; the actual magnitude depends largely on the vertical temperature gradient. This estimate is based on the findings of BROMWICH and FoGT (2004), who quantified this effect for several Antarctic stations. When taking into account this correction, ERA-Interim and HadGEM2 provide similar mean temperatures of about $-13{ }^{\circ} \mathrm{C}$.

Nevertheless, the reanalysis and model show positive near-surface temperature biases of about $3{ }^{\circ} \mathrm{C}$ compared to the measurements from Neumayer station. One possible explanation for this bias may lie in the underrepresentation in frequency and speed of katabatic winds as will be discussed in more detail in section 5. Another possible reason could be a misrepresentation of atmospheric stability or more specifically an underestimation of temperature inversions although ZHANG et al. (2011) show that ERA-Interim represents temperature inversions at Antarctic coastal stations reasonably well concerning frequency of appearance, depth, and intensity. Furthermore, the size of the model grid cells implies that the comparably warm sea surrounding the Neumayer station can also contribute to the warm bias. The differences in mean wind speed are remarkable. Again, different representations of the atmospheric stability especially for HadGEM2, but also orographic differences or differences in the large-scale circulation could play a role.

\section{Wind characteristics}

\subsection{Climatology of winds}

A two-dimensional frequency distribution of wind speed and direction during austral winter (JJA) is illustrated in Fig. 4(a). Again, it was decided to focus on the winter months only according to the reason given in section 3 .

The dominant wind direction at Neumayer station is easterly $\left(80-100^{\circ}\right)$ which can be found at approximately $45 \%$ of the days. Easterly winds also tend to show the highest wind speeds (up to $33 \mathrm{~m} / \mathrm{s}$ ). Other wind directions occur less frequently and are associated with lower wind speeds. Furthermore, there is hardly any occurrence of northerly winds $\left(310-50^{\circ}\right)$ at Neumayer station, which is a result of the fact that the vast majority of low pressure systems passes towards the north of Neumayer station at several degrees latitude distance (YUAN et al., 2009). Finally, it is found that the weakest winds (below $5 \mathrm{~m} / \mathrm{s}$ ) are associated with a southerly wind component $\left(140-220^{\circ}\right)$.

ERA-Interim as well as HadGEM2 are able to represent these gross features described above; however, there are a few differences (Fig. 4(b) and (c)): In ERA-Interim and HadGEM2 the dominating winds are coming from a wider range of directions, that is their direction is less well confined to the $80-100^{\circ}$ range as seen in the observations. Additionally, the magnitude of easterly winds is underrepresented. Furthermore, both ERA-Interim and HadGEM2 show a secondary maximum for south-westerly winds $\left(220-240^{\circ}\right)$ that is less well defined in the observations. At the same time, reanalyzed and simulated southerly winds $\left(160-220^{\circ}\right)$ are underrepresented compared to the observations. In the following subsections possible causes for wind differences at Neumayer station will be investigated in more detail.

\subsection{Geostrophic wind components}

In order to separate local effects on the winds at Neumayer station from those associated with the larger-scale atmospheric circulation, geostrophic winds were calculated from model output as described in section 2. The largest difference between actual and geostrophic wind can be explained by neglecting surface friction. In fact, the geostrophic winds show about 50\% higher wind speeds as well as a rotation of the wind direction of approximately $30^{\circ}$ to the left (in wind direction), which is in line with what is to be expected from Ekman spiral theory (EKMAN, 1905). Despite of the obvious and predictable short-coming of neglecting friction, a detailed analysis of geostrophic winds was found to be very useful.

Based on the geostrophic components of daily winds in ERA-Interim (Fig. 5(a)) as well as in HadGEM2 (Fig. 6(a)) it can be concluded that the dominant wind 


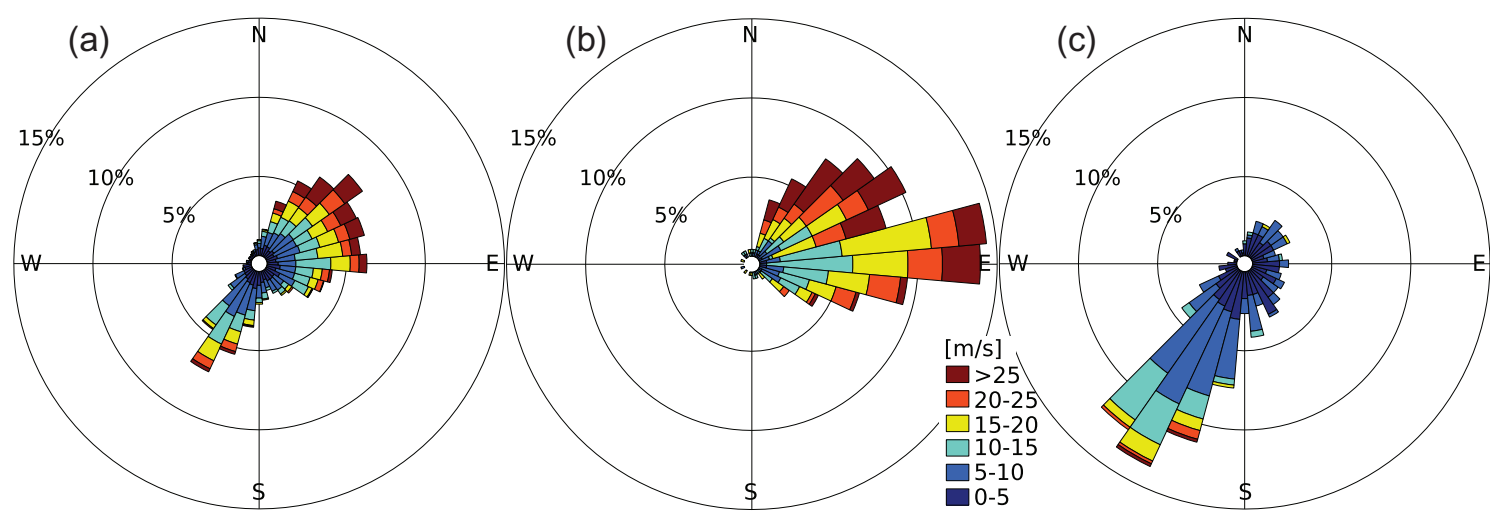

Figure 5: The geostrophic wind component in ERA-Interim for JJA from 1981-2011. (a) Climatology, (b) warm events, (c) cold events. A warm (cold) event is defined by a deviation in the observed $2 \mathrm{~m}$ temperature (the seasonal cycle has been subtracted) at Neumayer station at least one standard deviation above (below) its mean.

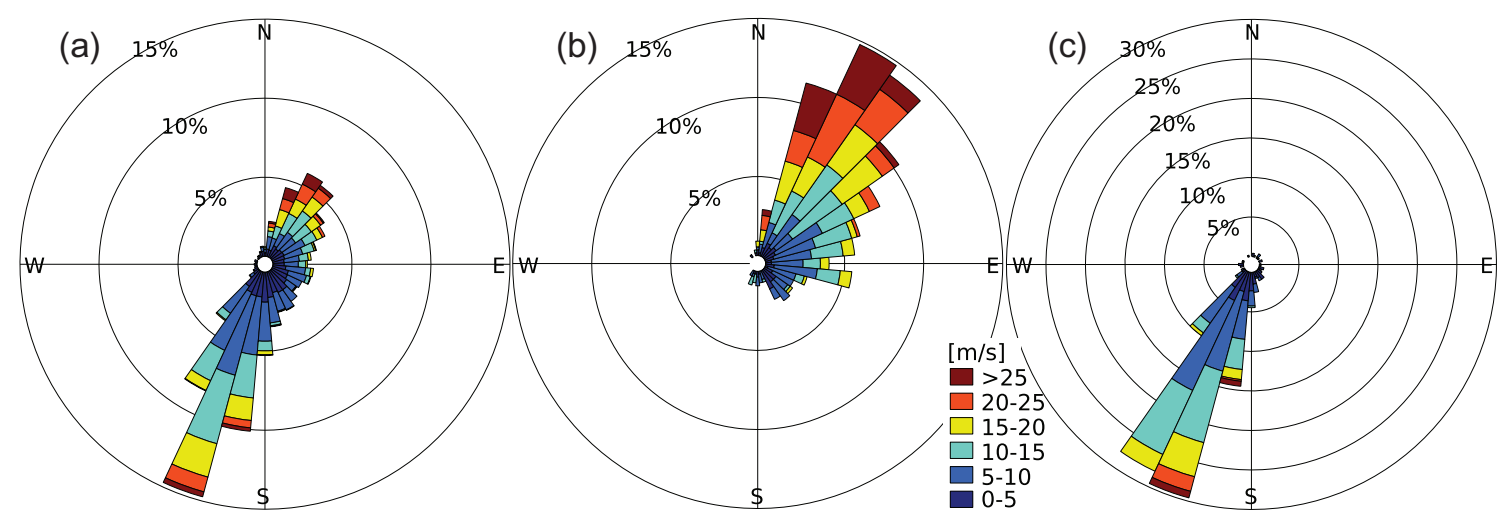

Figure 6: Same as Fig. 5 but for HadGEM2. Note the different frequency scaling of (c) compared to (a) and (b).

directions found in the full wind fields are primarily geostrophic, that is, they are dominated by synoptic-scale atmospheric circulation features. However, it is also found at Neumayer station that easterly winds experience a strong topographic steering in ERA-Interim and HadGEM2 as a broad range up to $70^{\circ}$ of the dominant wind direction (here: north to east) is turned into easterlies by the topography (Fig. 4(b) and (c)). The topographic steering occurs due to the terrain slope between sea level and Antarctic plateau, which leads to a parallelization of winds along the coast-line.

For south-westerly winds (the second most prominent wind direction) the frequency of geostrophically balanced winds is overestimated in the reanalysis and model. The relative importance of geostrophic wind components in explaining the full winds in ERA-Interim and HadGEM2 indicates that ageostrophic winds, such as katabatic winds, are underrepresented by ERA-Interim and HadGEM2 in frequency and speed. In order to provide further evidence for this statement winds were considered separately for anomalously cold and warm days at Neumayer station. Low temperatures should be associated with katabatic winds while anomalously high temperatures should go along with strong winds that are a result of synoptic disturbances leading to meridional heat exchange.

\subsection{Winds during anomalous temperatures at Neumayer station}

The observed winds at Neumayer station during warm events (see section 2 for details) are shown in Fig. 7(a). Approximately $90 \%$ of the anomalously warm cases are associated with easterly winds $\left(80-100^{\circ}\right)$ and magnitudes in the range from $10 \mathrm{~m} / \mathrm{s}$ to a maximum of $33 \mathrm{~m} / \mathrm{s}$ (11-12 Beaufort). In general, warm events are well represented in ERA-Interim and HadGEM2 (Fig. 7(b) and (c)). The geostrophic winds during warm events are shown in Fig. 5(b) and 6(b). It is clear that easterly winds are primarily geostrophically balanced with some additional influence from topographic steering as indicated by Fig. 7(b) and (c).

A completely different picture emerges when investigating the cold events: Fig. 8(a) shows that anomalously low temperatures occur simultaneously with weak southerly winds, which is consistent with the notion of a katabatic origin of the winds. Neither the reanalysis nor the 


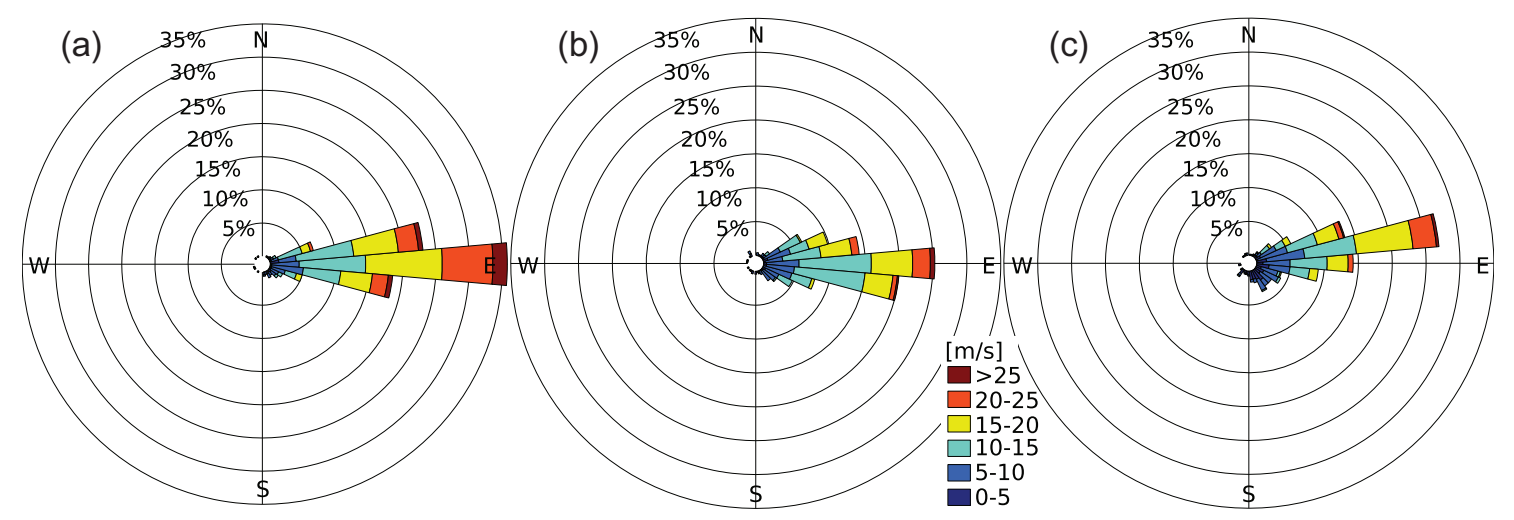

Figure 7: Comparison of warm events as described in Fig. 5 at Neumayer station during JJA: (a) Observations, (b) ERA-Interim and (c) HadGEM2.

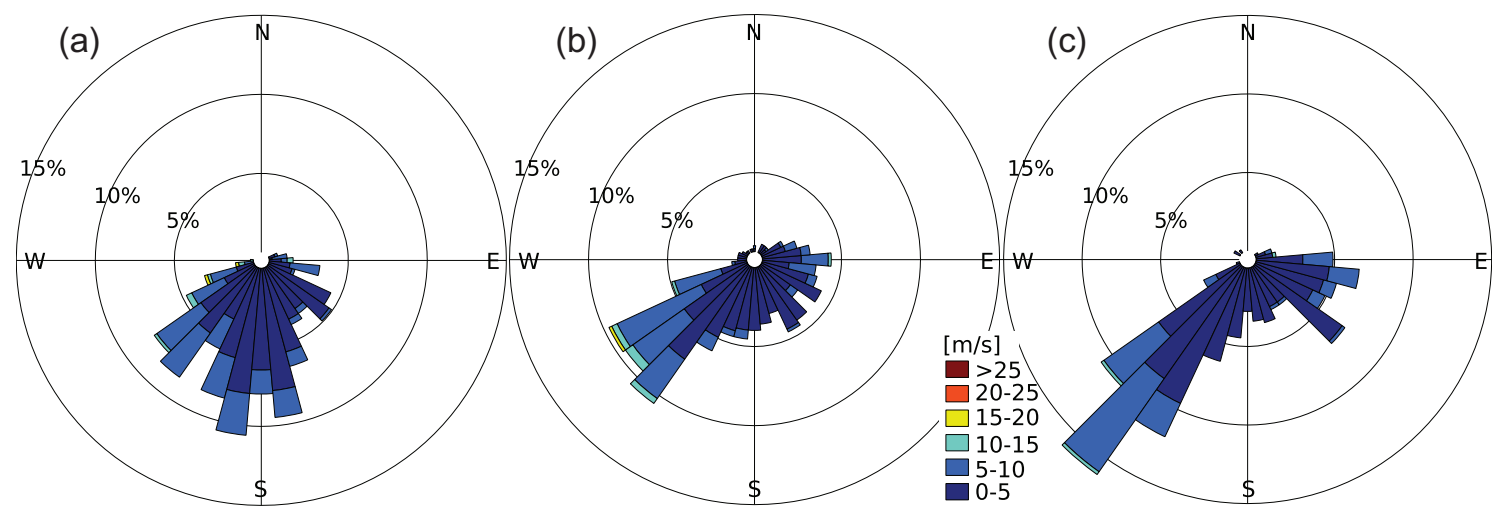

Figure 8: Same as Fig. 7 but for cold events.

model are capable to represent the observed frequency of occurrence of southerly winds; in fact, Fig. 8(b) and (c) shows mainly weak winds coming from the geostrophically dominated directions, south-west and east. The geostrophic component during cold events (Fig. 5(c) and 6(c)) needs to be discussed separately. The geostrophic component and the total wind in ERA-Interim are comparable during cold events (Fig. 5(c) and 8(b)) with the geostrophic component stronger and rotated anticlockwise compared to the total wind. Hence, ERA-Interim's ability to ageostrophic wind components with a katabatic origin during cold events is limited, which explains the deviation from the observations. The geostrophic wind in HadGEM2 comes from $190-220^{\circ}$ in about $80 \%$ of the cases. Therefore, cold events seem to be always connected to large-scale atmospheric circulation features affecting Neumayer station as shown in Fig. 9(b). As the geostrophic component is hardly comparable to the wind in Fig. 8(c) it is clear that the model is simulating ageostrophic winds even if they are not coming mainly from the south, and thus cannot be considered to be katabatic.

This leads to the conclusion, that complex ageostrophic winds such as katabatic winds are not well simulated in ERA-Interim and HadGEM2. In contrast, as shown by the warm events, ERA-Interim and HadGEM2 are able to simulate winds, which are mainly the result of the geostrophically balanced large-scale circulation, including some aspects of topographic steering. In general ERA-Interim appears to be more skillful in reproducing the winds at Neumayer station than HadGEM2, which is presumably a direct result of ERA-Interim's higher resolution. In fact, previous studies have demonstrated a better representation of katabatic winds in high-resolution regional climate models (MATHIOT et al. (2010); PETRELLI et al. (2008)).

\subsection{Wind fields around Neumayer station during warm and cold events}

In this subsection wind patterns over parts of the SH during warm and cold events are investigated. Fig. 9(a) and (b) display ERA-Interim fields of the median of wind speed and direction for all wintertime (JJA) warm and cold events, respectively. The application of median instead of commonly used arithmetic mean is useful given that wind speed is not a normally distributed variable, which leaves the arithmetic mean difficult to interpret in terms of its physical meaning. The significance has been tested using a Mann-Whitney-Wilcoxon test. The salient features shown in Fig. 9 are all significant 


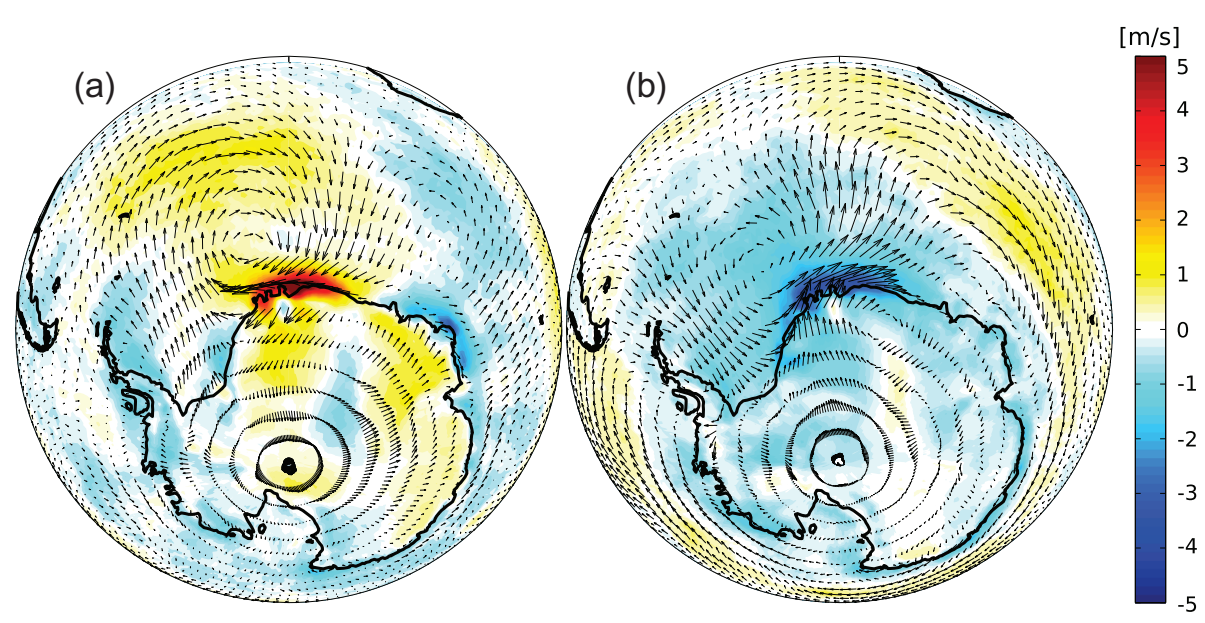

Figure 9: Composite map: Median of ERA-Interim daily anomalies during JJA in wind speed $[\mathrm{m} / \mathrm{s}]$ (shaded) and horizontal wind vectors: (a) warm events as described in caption of Fig. 5, (b) cold events.

at the $95 \%$-level under the hypothesis that the wind speed anomalies of warm and cold events come from a distribution with equal median (not shown); the test shows insignificant areas where the median windspeed of warm and cold events is approximately zero.

The composite map of warm events (Fig. 9(a)) highlights what has been discussed above: Warm events at Neumayer station are result of low pressure systems situated to the north. The associated winds transport relatively warm air of maritime origin to Neumayer station. In contrast, the composite map for cold events (Fig. 9(b)) displays roughly a signal of the opposite sign: The low pressure area is replaced by a high pressure ridge which reduces the wind speed around Neumayer station by up to $4 \mathrm{~m} / \mathrm{s}$ relative to the climatological mean; these findings are consistent with results from KöNIGLANGLO and LOOSE (2007). In addition, katabatic winds south of Neumayer station can be seen for cold events. The results presented in section 5 suggest that the speed of katabatic winds tends to be underestimated.

High and low pressure systems in the vicinity of Neumayer station are associated with cloud cover changes. This is consistent with low temperatures due to clear sky and a negative radiation budget during winter as well as with high temperatures due to reflected radiation from clouds.

\section{Conclusions}

The meteorological measurements at the Neumayer station have been found to have a spatial footprint on the interior of the Antarctic beyond the South Pole as well as on parts of the Southern Ocean. This is an important result given the sparseness of observational data in and around Antarctica. Furthermore, sea level pressure anomalies at Neumayer station have been found to be linked significantly to the Southern Annular Mode (SAM).
Strong spurious trends of up to $7^{\circ} \mathrm{C}$ over 31 years have been identified in the ERA-Interim reanalysis at certain locations in Antarctica. Other reanalyses also show shortcomings (BRACEGIRDLE and MARSHALL, 2012). In contrast, no significant temperature trend is observed at Neumayer station. This is a strong reminder that reanalysis data need to be used with caution on the Antarctic continent and that the long-term maintenance of stations such as Neumayer is crucial to retain our capabilities to monitor possible anthropogenic change in Antarctica and over the Southern Ocean.

Anomalously low temperatures at Neumayer are mostly connected to weak katabatic winds coming from the interior of the Antarctic continent. In contrast, high temperatures at Neumayer are mostly connected to strong easterly winds. Geostrophic winds from northeasterly and easterly directions are channelled into easterly winds along the topographic slope of the Antarctic coast and bring relatively warm air due to heat transport from synoptic disturbances.

Several shortcomings of ERA-Interim as well as HadGEM2 have been found in this study. Section 5 points out that even though the representation of katabatic winds is better at higher resolution, katabatic winds at approximately $80 \mathrm{~km}$ resolution as used in ERA-Interim are still far from satisfactory. This relative lack of katabatic winds in model products may partly explain the warm temperature biases of about $3{ }^{\circ} \mathrm{C}$ in ERA-Interim and HadGEM2. In contrast, the simulation of synoptic-scale motions, as shown by the warm events, is very realistic in both reanalysis and model.

\section{Acknowledgments}

This paper is the result of an internship of the lead author at the AWI in 2012/13. We acknowledge the World Climate Research Programme's Working Group on Coupled Modelling, which is responsible for CMIP, 
and we thank the climate modeling groups for producing and making available their model output.

\section{References}

Arora, V.K., J.F. ScINOCCA, G.J. BOER, J.R. ChristiAn, K.L. Denman, G.M. Flato, V.V. Kharin, W.G. LeE, W.J. MERRYFIELD, 2011: Carbon emission limits required to satisfy future representative concentration pathways of greenhouse gases. - Geophys. Res. Lett. 38, 1-6.

BracegirdLE, T.J., G.J. MARShall, 2012: The Reliability of Antarctic Tropospheric Pressure and Temperature in the Latest Global Reanalyses. - J. Climate 25, 7138-7146.

Bromwich, D., R.L. Fogt, 2004: Strong Trends in the Skill of the ERA-40 and NCEP-NCAR Reanalyses in the High and Midlatitudes of the Southern Hemisphere, 1958-2001. - J. Climate 17, 4603-4619.

Bromwich, D.H., J.P. Nicolas, A.J. Monaghan, M.A. LAZZARA, L.M. Keller, G.A. WeIDNER, A.B. Wilson, 2013: Central West Antarctica among the most rapidly warming regions on Earth. - Nature Geosci. 6, 139-145.

Chapman, W.L., J.E. WALSh, 2007: A Synthesis of Antarctic Temperatures. - J. Climate 20, 4096-4117.

Collins, W.J., N. Bellouin, M. DOUTRiauX-Boucher, N. Gedney, P. Halloran, T. Hinton, J. Hughes, C.D. JONES, M. JOSHI, S. LIDDICOAT, G. MARTIN, F, O’CONNOR, J. RAE, C. SENIOR, S. SITCH, I. TOTTERDELL, A. Wiltshire, S. WoOdWARD, 2011: Development and evaluation of an Earth-System model - HadGEM2. - Geosci. Model Dev. 4, 1051-1075.

DeE, D.P., S.M. Uppala, A.J. Simmons, P. Berrisford, P. Poli, S. Kobayashi, U. Andrae, M.A. Balmaseda, G. BAlsamo, P. BAuer, P. BeChtold, A.C.M. BeljaArs, van.de.L. BERG, J. BIDLOT, N. BORMANN, C. DELSOL, R. Dragani, M. Fuentes, A.J. GEer, L. HAIMBERGER, S.B. Healy, H. Hersbach, E.V. Hólm, L. Isaksen, P. KÅllberG, M. KÖHLER, M. MATRICARDI, A.P. MCNALLY, B.M. MOnge-SAnZ, J.-J. MORCRETTE, B.-K. PARK, C. Peubey, P. De Rosnay, C. Tavolato, J.-N. ThéPaut, F. VITART, 2011: The ERA-interim reanalysis: configuration and performance of the data assimilation system. - Quart. J. Roy. Meteor. Soc. 137, 553-597.

EKMAN, V.W., 1905: On the influence of the earth's rotation on ocean currents. - Ark. Mat. Astron. Fys. 2, 1-52.

GONG, D., S. WANG, 1999: Definition of Antarctic oscillation index. - Geophys. Res. Lett. 26, 459-462.

HALL, A., M. VISBECK, 2002: Synchronous Variability in the Southern Hemisphere Atmosphere, Sea Ice, and Ocean resulting from the Annular Mode. - J. Climate 15, 3043-3057.

Jones, C.D., J.K. Hughes, N. Bellouin, S.C. HARdiman, G.S. JONES, J. KNIGHT, S. LIDDICOAT, F.M. O'CONNOR, R.J. ANDRES, C. BELl, K.-O. Boo, A. Bozzo, N. Butchart, P. CAdule, K.D. Corbin, M. DoutriauXBOUCher, P. Friedlingstein, J. GORnALl, L. GRAY, P.R. HALloran, G. HuRTt, W.J. IngRAM, J.-F. LAMARQUE, R.M. LaW, M. Meinshausen, S. OsPrey, E.J. Palin, L.
Parsons Chini, T. Raddatz, M.G. SANDERSON, A.A. SEllar, A. SCHURER, P. VALDES, N. WOOD, S. WOODWARD, M. YoshioKA, M. ZERroukAT, 2011: The HadGEM2-ES implementation of CMIP5 centennial simulations. - Geosci. Model Dev. 4, 543-570.

KlÖWER, M., T. Jung, G. KÖNIG-LANGlo, T. SEMmler, 2013: Meteorological synoptical observations from Neumayer Station, 1981-03 to 2011-12. - PANGAEA, reference list of 372 datasets, doi: 10.1594/ PANGAEA.810182.

KÖNIG-LANGLO, G., B. LoOSE, 2007: The meteorological Observatory at Neumayer Stations (GvN and NM-II) Antarctica. - Polarforschung 76, 25-38.

MANN, H.B., D.R. WHITNEY, 1947: On a test of whether one of two random variables is stochastically larger than the other. - Ann. Math. Statist. 18-1, 50-60.

Mathiot, P., B. BARnier, H. Gallée, J.M. Molines, J. Le SOMMER, M. JUZA, T. PENDUFF, 2010: Introducing katabatic winds in global ERA40 fields to simulate their impacts on the Southern Ocean and sea-ice. - Ocean Modell. 35, 146-160.

Meinshausen, M., S.J. Smith, K. Calvin, J.S. Daniel, M.L.T. KaINUMA, J.-F. LAmarque, K. MatSUmoto, S.A. MONTZKA, S.C.B. RAPER, K. RiAHI, A. THOMSON, G.J.M. VELDERS, D.P. VAN VUUREN, 2011: The RCP greenhouse gas concentrations and their extensions from 1765 to 2300. - Climate Change 109, 213-241.

Monaghan, A.J., D.H. Bromwich, J.G. Powers, K.W. MANNING, 2005: The Climate of the McMurdo, Antarctica, Region as Represented by One Year of Forecasts from the Antarctic Mesoscale Prediction System. - J. Climate 18, 1174-1189.

Monaghan, A.J., D.H. BROMwich, W. Chapman, J.C. COMISO, 2008: Recent variability and trends of Antarctic near-surface temperature. - J. Geophys. Res. 113, 1-21.

PARISH, T.R., 1988: Surface winds over the Antarctic continent: a review. - Rev. Geophys. 26, 169-180.

PARISH, T.R., D.H. BROMWICH, 2007: Reexamination of the Near-Surface Airflow over the Antarctic Continent and Implications on Atmospheric Circulations at High Southern Latitudes. - Mon. Wea. Rev. 135, 1961-1973.

Petrelli, P., N.L. Bindhoff, A. Bergamasco, 2008: The sea ice dynamics of Terra Nova Bay and Ross Ice Shelf Polynyas during a spring and winter simulation. - J. Geophys. Res. 113, C09003.

Rimbu, N., G. LOHMANN, G. KÖNIG-LANGlo, C. NeCUlA, M. IONITA, 2013: Daily to intraseasonal oscillations at Antarctic research station Neumayer. - Antarctic Science, published online August 13, 2013, doi: http://dx.doi.org/ 10.1017/S0954102013000540.

RODRIGO, J.S., J.-M. BUCHLIN, J. VAN BEECK, J.T.M. LENAERTS, M.R. VAN DEN BROEKE, 2013: Evaluation of the antarctic surface wind climate from ERA reanalyses and RACMO2/ANT simulations based on automatic weather stations. - Climate Dynam. 40, 353-376.

Steig, E.J., D.P. SCHNEIDER, S.D. RUTHERFORD, M.E. MANN, J.C. COMISO, D.T. SHINDELL, 2009: Warming of 
the Antarctic ice-sheet surface since the 1957 International Geophysical Year. - Nature 457, 459-462.

Thompson, D.W.J., S. SOlOMON, 2002: Interpretation of Recent Southern Hemisphere Climate Change. - Science 296, 895-899.

Thompson, D.W.J., J.M. WALlace, 2000: Annular Modes in the Extratropical Circulation. Part I: Month-to-Month Variability. - J. Climate 13, 1000-1016.

Turner, J., S.R. COlWEll, G.J. Marshall, T.A. LACHLAN-COPE, A.M. CARLETON, P.D. JONES, V. LAGUN, P.A. REID, S. IAGOVKINA, 2005: Antarctic climate change during the last 50 years. - Int. J. Climatol. 25, 279-294.

Turner, J., S.N. Chenoli, A. ABu SAmah, G. Marshall, T. PHILliPS, A. ORR, 2009: Strong wind events in the Antarctic. - J. Geophys. Res. 114, D18103, doi: 10.1029/ 2008JD011642.
VAN DEN BROEKE, M.R., R.S.W. VAN DE WAL, M. WILD, 1997: Representation of Antarctic Katabatic Winds in a High-Resolution GCM and a Note on Their Climate Sensitivity. - J. Climate 10, 3111-3130.

VAN LIPZIG, N.P.M., J. TURNER, S.R. COLWELL, M.R. VAN DEN BROEKE, 2004: The near-surface wind field over the Antarctic continent. - Int. J. Climatol. 24, 1973-1982.

VISBECK, M., 2009: A Station-Based Southern Annular Mode Index from 1884 to 2005. - J. Climate 22, 940-950.

YuAn, X., J. PATOUX, C. LI, 2009: Satellite-based midlatitude cyclone statistics over the Southern Ocean: 2. Tracks and surface fluxes. - J. Geophys. Res. 114, D04106, published online, doi: 10.1029/2008JD010874.

Zhang, Y., D.J. SeIDEL, J.-C. GolaZ, C. Deser, R.A. TOMAS, 2011: Climatological Characteristics of Arctic and Antarctic Surface-Based Inversions. - J. Climate 24, 5167-5186. 